\title{
Global governance principles for the sustainable development of groundwater resources
}

\author{
Kirstin I. Conti ${ }^{1,2}$ (D) Joyeeta Gupta ${ }^{3,4}$
}

Accepted: 8 December 2015/Published online: 24 December 2015

(C) The Author(s) 2015. This article is published with open access at Springerlink.com

\begin{abstract}
A normative framework for the governance of groundwater is emerging at the global level. However, existing analyses have not comprehensively covered all the governance texts that have a bearing on transboundary groundwater resources or looked at them from the perspective of sustainable groundwater governance. Therefore, this paper responds to the questions: What are the global governance texts (including international laws) applicable to groundwater resources; to which forms of the resource do they apply; which principles have been included over time; and what are the implications for sustainable development of groundwater resources now and in the future? The analysis highlights key groundwater concepts, discusses twelve global groundwater governance texts and the thirty principles therein, classifies the principles into ideal-typical categories based on the sustainable development concept; and assesses the gaps and conflicts between the principles and texts. The paper has three key findings. First, groundwater governance is rapidly evolving and there are a number of principles available to promote sustainable development. Second, however, these collective principles do not adequately address (a) the link with all water resources; (b) the potential impact of climate change on water resources; and (c) the impact of trade on equitable sharing of groundwater and protection
\end{abstract}

Kirstin I. Conti

k.i.conti@uva.nl; kirstin.conti@un-igrac.org

Joyeeta Gupta

j.gupta@uva.nl; j.gupta@unesco-ihe.org

1 Governance and Inclusive Development, Amsterdam Institute for Social Science Research (AISSR), University of Amsterdam, Nieuwe Actergracht 166, 1018 WV Amsterdam, The Netherlands

2 International Groundwater Resources Assessment Centre (IGRAC), Westvest 7, 2611 AX Delft, The Netherlands

3 UNESCO-IHE Institute for Water Education, Westvest 7, 2611 AX Delft, The Netherlands

4 Department of Geography, Planology and International Development Studies, Faculty of Social and Behavioural Sciences, Amsterdam Institute of Social Science Research, University of Amsterdam, Room 2.12b, Plantage Muidergracht 14, 1018 TV Amsterdam, The Netherlands 
of groundwater-related ecosystems. Third, to the extent that this collection of principles can contribute to sustainable development, they are inconsistently included in the legally binding groundwater governance texts. Therefore, much progress is needed to ensure a global normative framework that can guide the sustainable governance of groundwater resources.

Keywords Groundwater governance - Transboundary aquifers - Sustainable development · Groundwater sustainability · International groundwater law · Law of transboundary aquifers · Principles for groundwater governance

$\begin{array}{ll}\text { Abbreviations } \\ \text { ECOSOC } & \text { United Nations Economic and Social Council } \\ \text { HRC } & \text { Human Rights Council } \\ \text { ICJ } & \text { International Court of Justice } \\ \text { ICWE } & \text { International Conference on Water and the Environment } \\ \text { IGRAC } & \text { International Groundwater Resources Assessment Centre } \\ \text { ILA } & \text { International Law Association } \\ \text { ILC } & \text { International Law Commission } \\ \text { IWRM } & \text { Integrated Water Resources Management } \\ \text { PCA } & \text { Permanent Court of Arbitration } \\ \text { SDGs } & \text { Sustainable Development Goals } \\ \text { UN } & \text { United Nations } \\ \text { UNCED } & \text { United Nations Conference on Environment and Development } \\ \text { UNECE } & \text { United Nations Economic Commission for Europe } \\ \text { UNESCO } & \text { United Nations Educational, Scientific and Cultural Organization } \\ \text { UNGA } & \text { United Nations General Assembly } \\ \text { WCED } & \text { World Commission on Environment and Development }\end{array}$

\section{Introduction}

Groundwater constitutes 98-99 \% of the world's available freshwater resources (Margat and van der Gun 2013: p. 5). Nearly 600 groundwater resources traverse political boundaries (International Groundwater Resources Assessment Centre (IGRAC) 2015a, b), and an unknown number solely reside within country borders. Approximately, $25 \%$ of humans rely on groundwater for their domestic needs (Machard de Gramont et al. 2011) and $50 \%$ use it for potable water supply (Mechlem 2003). Groundwater supplies over $40 \%$ of irrigation needs globally (Döll and Hoffmann-Dobrev 2012; Siebert et al. 2010), partly due to increased reliability of individual irrigation wells over public surface water distribution schemes (Shah 2009a). Additionally, groundwater makes up $50 \%$ of municipal and $40 \%$ of industrial water withdrawals (Zektser and Everett 2004); thereby catalyzing growth, development and poverty alleviation (Shah 2009b; Wijnen et al. 2012). However, many aquifers are in jeopardy due to poor governance (Llamas and MartínezSantos 2005) and insufficient legal frameworks that lack consideration for hydrogeological complexities and/or socio-political, environmental and economic aspects.

The literature has analyzed individual treaties (Eckstein 2007; McCaffrey 2011; McIntryre 2006; McIntyre 2011) or a combination thereof (Dellapenna 2011; Eckstein and 
Sindico 2014; Mechlem 2003). Several analyses relate to the six transboundary aquifers that have aquifer-specific legal mechanisms; ${ }^{1}$ others to one or more of the 89 out of 196 countries that have groundwater regulations (IGRAC 2015a, b). However, no one has comprehensively assessed the norms in all relevant groundwater governance texts from the perspective of sustainable groundwater governance. Such an assessment becomes all the more relevant in the light of the recent entry into force of the United Nations Convention on the Law of the Non-Navigational Uses of International Watercourses (UN Watercourses Convention 1997); the opening of the United Nation Economic Commission for Europe Convention on the Protection and Use of Transboundary Watercourses and International Lakes (UNECE Convention 1992) to accession by all UN member states (see Sect. 3); and the September 2015 adoption of the Sustainable Development Goals by 193 UN member states (UN SDGs 2015). Hence, this paper addresses the questions: What global governance texts apply to groundwater resources; to which types of groundwater resources do they apply; which principles have been included over time; and what are the implications for sustainable development of groundwater resources now and in the future?

This paper treats sustainable development and Integrated Water Resources Management (IWRM) as overarching concepts, rather than single principles; although they are mentioned as principles in several governance texts. ${ }^{2}$ Sustainable development "aims to meet the needs of present generations without compromising on the ability of future generations to meet their own needs" (WCED 1987: 43) and can be operationalized through legal principles (Fuentes 2002; Rieu-Clarke 2000). Groundwater sustainability implies the development and use of groundwater without causing unacceptable long-term environmental, economic or social consequences through integrated, adaptive and inclusive governance (Custodio 2002; Gleeson et al. 2012; Gleeson and VanderSteen 2010; Llamas et al. 1992). IWRM calls for coordinated management of water-related resources (Biswas 2004; Global Water Partnership 2002: 22); adaptive governance for dealing with the inherent uncertainties of the system; and inclusive governance to focus on the socioecological dimensions.

This paper explains key groundwater concepts (see Sect. 2), global groundwater governance texts (see Sect. 3), and assesses the principles that emerge from these texts in terms of social, environmental and economic dimensions of sustainable development (see Sect. 4); before drawing conclusions (see Sect. 5).

\section{Groundwater: physical and political typologies}

Groundwater is water that fully saturates the pores and cracks of the earth's subsurface geology (Fitts 2002). It is primarily formed after percolating from the earth's surface through the soil and into the underlying geological formation, but it may have also been trapped during geologic processes, such as sedimentation or volcanic activity. Depending on the geology below (e.g., sand, clay, gravel, fractured rock), groundwater can accumulate into a distinct formation called an aquifer and often flows slowly through the subsurface.

\footnotetext{
1 These agreements are listed in Eckstein and Sindico's (2014) publication. Since then, the Al-Sag/Al-Disi Aquifer Agreement (2015) was signed.

2 Sustainable development is included as a principle in the UN Rio Declaration (1992), UNECE Convention (1992) and Protocol (1999) as "sustainable use," ILA Berlin Rules (2004) as "sustainable use" and action agenda of the ICWE Dublin Statement (1992). IWRM is included in the ILA Seoul Rules (1986), UN Agenda 21 (1992), and ILA Berlin Rules (2004).
} 
An aquifer is a permeable layer of underground rock, which is saturated with and capable of yielding groundwater (Fetter 2001; Fitts 2002). Sometimes a groundwater resource is only defined as an aquifer when it has yield sufficient for human use. Aquifers can be unconfined, where the water table occurs within the aquifer layer and the groundwater is in direct contact with the atmosphere through soil pores, or confined, where it is over- and underlain by a semipermeable or impermeable layer (Fitts 2002; Margat and van der Gun 2013). A nonrecharging aquifer, containing "fossil" groundwater, does not receive meaningful recharge on a human timescale. Political typologies of aquifers include national aquifers completely contained within state boundaries; national aquifers hydrologically linked with international watercourses; and transboundary aquifers shared by two or more states.

\section{Evolution of groundwater governance texts at the global level}

This section discusses global groundwater governance texts (see Table 1) in terms of the political and hydro(geo)logical typologies mentioned above (see Table 2). Scholars within the International Law Association (ILA) codified the principles for governing international rivers in the non-binding Helsinki Rules on the Uses of the Waters of International Rivers (ILA Helsinki Rules 1966). In Article II, an International Drainage Basins is defined as a "geographical area extending over two or more States...including surface and underground waters flowing to a common terminus." This includes groundwater that is hydrologically connected to a transboundary surface water feature and flows toward a common point of discharge area.

In 1972, the world's first environmental conference adopted the Declaration of the United Nations Conference on the Human Environment which addressed human-environment interactions and water resources (UN Stockholm Declaration 1972, Preamble, Principle 2). The UN's first water conference adopted the Mar del Plata Action Plan and Recommendations (UN Mar del Plata Plan 1977) clarifying norms for water management and mentioning groundwater in relation to water supply for domestic and agricultural use.

In 1986, the ILA published its Seoul Rules on International Groundwaters (ILA Seoul Rules 1986), where these scholars already suggested focusing on aquifers, not groundwater. It went beyond the Helsinki Rules to include: "the waters of an aquifer that is intersected by the boundary between two or more States [...] whether or not the aquifer and its waters form surface waters part of a hydraulic system flowing into a common terminus" (Article I, emphasis added).

In 1992, at the second global environmental conference, the Brundtland Commission's exploration of sustainable development (WCED 1987) and the UN Stockholm Declaration (1972) influenced the Rio Declaration on Environment and Development (UN Rio Declaration 1992) and the accompanying non-binding action plan, Agenda 21 (1992) (Dellapenna and Gupta 2009). The Rio Declaration contains 27 environmental governance principles some of which are further assessed here; Agenda 21 is highlighted where relevant. That same year, many countries and NGOs adopted the ICWE Dublin Statement on Water and Sustainable Development (ICWE Dublin Statement 1992) at the International Conference on Water and the Environment with four principles recognizing the finite nature of water, the need for participatory processes, the role of women, and water as an economic good.

In the same year, the UN Economic Commission for Europe adopted the regional, Convention on the Protection and Use of Transboundary Watercourses and International Lakes (UNECE 1992). It covers "ground waters...which mark, cross or are located on boundaries between two or more States" (UNECE 1992: Art. 1.1). Its Protocol on Water and Health (UNECE 1999) focuses on protecting human health and well-being through 
water management. In 2013, amendments allowing all UN member states to accede to it entered into force (UNECE 2003) — making it global. In 2014, the UNECE adopted Model Provisions on Transboundary Groundwater Management, which "provide practical guidance" and "offer assistance" to the parties in creating agreements for the sustainable use, management and protection of groundwater (UNECE 2014: p. 3, para. 9). These Provisions apply both to groundwater and the geological formation containing the groundwater, subtly shifting from groundwater to aquifer.

In 1997, the UN member states adopted the UN Watercourses Convention (1997), culminating a 30-year process led by the UN's International Law Commission (ILC). It entered into force in 2014 and is binding for its parties. This Convention applies to international watercourses defined as a "system of surface waters and groundwaters constituting by virtue of their physical relationship a unitary whole and normally flowing into a common terminus [...] parts of which are situated in different States" (UN Watercourses Convention 1997, Article 2a). It focuses on surface water systems and some connected groundwater resources. There is debate as to whether it applies to two situations: first, where an aquifer hydrologically links two surface water bodies with different termini and second where a confined aquifer is linked to an unconfined aquifer or surface water body but would still constitute distinct systems rather than a "unitary whole" (Mechlem 2003). This issue is being gradually clarified by legal experts. However, the UN Watercourses Convention does not cover aquifers that lack hydrologic connection to surface water.

This gap was addressed in the ILA's non-binding Berlin Rules on Water Resources (ILA Berlin Rules 2004), which updated its Helsinki Rules. The ILA Berlin Rules proposes that states apply the rules to transboundary and national resources, "as appropriate" (ILA 2004b: Article 1.2; Dellapenna 2011) and are controversial as a result (Bogdanovic et al. 2004). Nevertheless, its contents contribute to normative developments in groundwater governance.

The UN ILC prepared the Draft Articles on the Law of Transboundary Aquifers (ILC Draft Articles 2008) in response to the gap in scope of the UN Watercourses Convention and the developments in the ILA Berlin Rules. The Draft Articles define an aquifer as "a permeable water-bearing geological formation underlain by a less permeable layer and the water contained in the saturated zone of the formation" and include all aquifers where its "parts ... are situated in different States" (ILC Draft Articles 2008: Art. 2a, 2c). Although thrice reviewed by UN member states, delegates still disagree about whether the Draft Articles should be a declaration of principles, an international framework convention, or remain a non-legally binding document. Consequently, it is a provisional agenda item for the UNGA's 71st session in September 2016.

The UN Human Rights Commission and UNGA adopted resolutions on the human right to water and sanitation in 2010, not only advancing rights-based approaches to (ground)water governance, but also having implications for the use and development of all groundwater resources (UN HRC 2010; UNGA 2010). In September 2015, the UN member states adopted the SDGs, which calls for the sustainable management of all fresh water resources. It implicitly includes groundwater, but does not apply any principles specifically to it.

Thus, the evolution of global groundwater governance texts has been nonlinear, influenced by developments in different fora, and is rapidly accelerating (see Table 1). This evolution has resulted in texts defining and including groundwater differently in their scopes (see Table 2). Only the Berlin Rules and Draft Articles explicitly define an aquifer and mention "layers of geological strata" (Article 3.2 in ILA 2004) and "aquifer systems" respectively (Eckstein 2007; ILC 2008). The Helsinki Rules and UN Watercourses Convention are ambiguous with respect to the types of links between ground and surface water, including multilayered aquifer systems. 
Table 1 Status and ratifications of governance texts applicable to groundwater resources

\begin{tabular}{|c|c|c|c|c|c|}
\hline Text & Date & Legal status & Ratifying parties & & \\
\hline ILA Helsinki Rules & 1966 & $\begin{array}{l}\text { Academic list of } \\
\text { rules, non-binding }\end{array}$ & Not applicable & & \\
\hline $\begin{array}{l}\text { UN Stockholm } \\
\text { Declaration }\end{array}$ & 1972 & $\begin{array}{l}\text { Adopted by states, } \\
\text { non-binding rules }\end{array}$ & Not applicable & & \\
\hline $\begin{array}{l}\text { UN Mar del Plata } \\
\text { Action Plan }\end{array}$ & 1977 & $\begin{array}{l}\text { Adopted by states, } \\
\text { non-binding rules }\end{array}$ & Not applicable & & \\
\hline ILA Seoul Rules & 1986 & $\begin{array}{l}\text { Academic list of } \\
\text { rules, non-binding }\end{array}$ & Not applicable & & \\
\hline ICWE Dublin Statement & 1992 & $\begin{array}{l}\text { Adopted, non-binding } \\
\text { principles }\end{array}$ & Not applicable & & \\
\hline UN Rio Declaration & 1992 & $\begin{array}{l}\text { Adopted, non-binding } \\
\text { declaration }\end{array}$ & Not applicable & & \\
\hline UNECE Convention & 1992 & $\begin{array}{l}\text { Ratified, in-force } \\
\text { treaty }\end{array}$ & $\begin{array}{l}\text { Albania } \\
\text { Austria } \\
\text { Azerbaijan } \\
\text { Belarus } \\
\text { Belgium } \\
\text { Bosnia and } \\
\quad \text { Herzegovina } \\
\text { Bulgaria } \\
\text { Croatia } \\
\text { Czech Rep } \\
\text { Denmark } \\
\text { Estonia } \\
\text { E.U. } \\
\text { Finland } \\
\text { Latvia }\end{array}$ & \begin{tabular}{l} 
Liechtenstein \\
Lithuania \\
France \\
Germany \\
Greece \\
Hungary \\
Italy \\
Kazakhstan \\
Luxembourg \\
Netherlands \\
Norway \\
Poland \\
Portugal \\
Republic of \\
\multicolumn{1}{c}{ Moldova }
\end{tabular} & $\begin{array}{l}\text { Romania } \\
\text { Russia } \\
\text { Serbia } \\
\text { Slovakia } \\
\text { Slovenia } \\
\text { Spain } \\
\text { Sweden } \\
\text { Switzerland } \\
\text { Turkmenistan } \\
\text { Ukraine } \\
\text { U.K. } \\
\text { Uzbekistan }\end{array}$ \\
\hline $\begin{array}{l}\text { UN Watercourses } \\
\text { Convention }\end{array}$ & 1997 & $\begin{array}{l}\text { Ratified, in-force } \\
\text { treaty }\end{array}$ & $\begin{array}{l}\text { Benin } \\
\text { Burkina Faso } \\
\text { Chad } \\
\text { Côte d'Ivoire } \\
\text { Denmark } \\
\text { Finland } \\
\text { France } \\
\text { Germany } \\
\text { Greece } \\
\text { Guinea-Bissau } \\
\text { Hungary } \\
\text { Iraq } \\
\text { Ireland }\end{array}$ & $\begin{array}{l}\text { Italy } \\
\text { Jordan } \\
\text { Lebanon } \\
\text { Libya } \\
\text { Luxembourg } \\
\text { Montenegro } \\
\text { Morocco } \\
\text { Namibia } \\
\text { Netherlands } \\
\text { Niger } \\
\text { Nigeria } \\
\text { Norway } \\
\text { Palestine }\end{array}$ & $\begin{array}{l}\text { Paraguay } \\
\text { Portugal } \\
\text { Qatar } \\
\text { South Africa } \\
\text { Spain } \\
\text { Sweden } \\
\text { Syria } \\
\text { Tunisia } \\
\text { U.K. } \\
\text { Uzbekistan } \\
\text { Venezuela } \\
\text { Viet Nam } \\
\text { Yemen }\end{array}$ \\
\hline UNECE Protocol & 1999 & $\begin{array}{l}\text { Ratified, in-force } \\
\text { protocol to treaty }\end{array}$ & $\begin{array}{l}\text { Albania } \\
\text { Azerbaijan } \\
\text { Belarus } \\
\text { Belgium } \\
\text { Bosnia and } \\
\quad \text { Herzegovina } \\
\text { Croatia } \\
\text { Czech Republic } \\
\text { Estonia } \\
\text { Finland }\end{array}$ & $\begin{array}{l}\text { France } \\
\text { Germany } \\
\text { Hungary } \\
\text { Latvia } \\
\text { Lithuania } \\
\text { Luxembourg } \\
\text { Netherlands } \\
\text { Norway } \\
\text { Moldova } \\
\text { Portugal }\end{array}$ & $\begin{array}{l}\text { Romania } \\
\text { Russia } \\
\text { Serbia } \\
\text { Slovakia } \\
\text { Spain } \\
\text { Switzerland } \\
\text { Ukraine }\end{array}$ \\
\hline ILA Berlin Rules & 2004 & $\begin{array}{l}\text { Academic list of } \\
\text { rules, non-binding }\end{array}$ & Not applicable & & \\
\hline ILC Draft Articles & 2008 & $\begin{array}{l}\text { Awaiting adoption by } \\
\text { states }\end{array}$ & Not applicable & & \\
\hline UN HRC; UNGA & 2010 & $\begin{array}{l}\text { Adopted, non-binding } \\
\text { resolutions }\end{array}$ & Not applicable & & \\
\hline
\end{tabular}




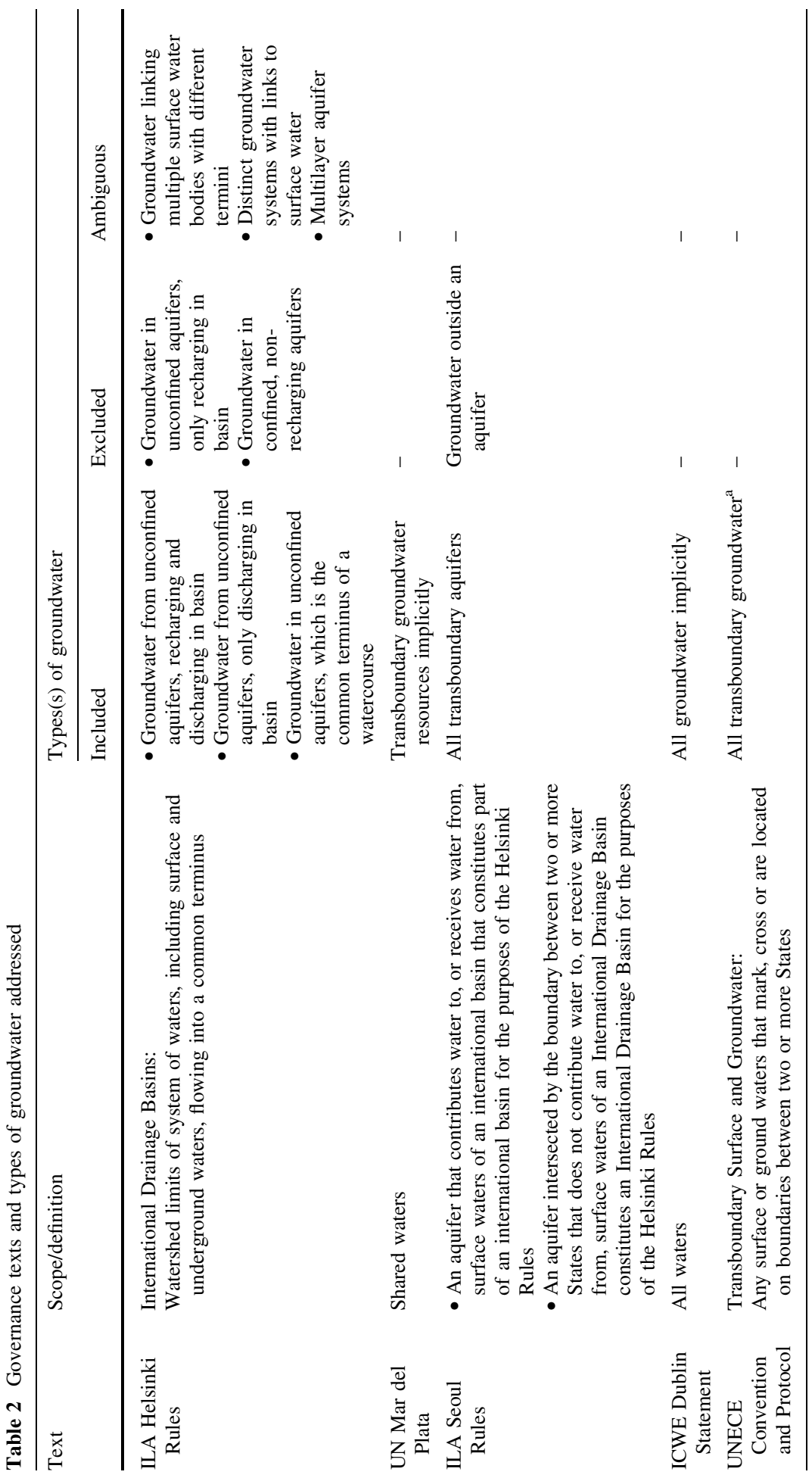




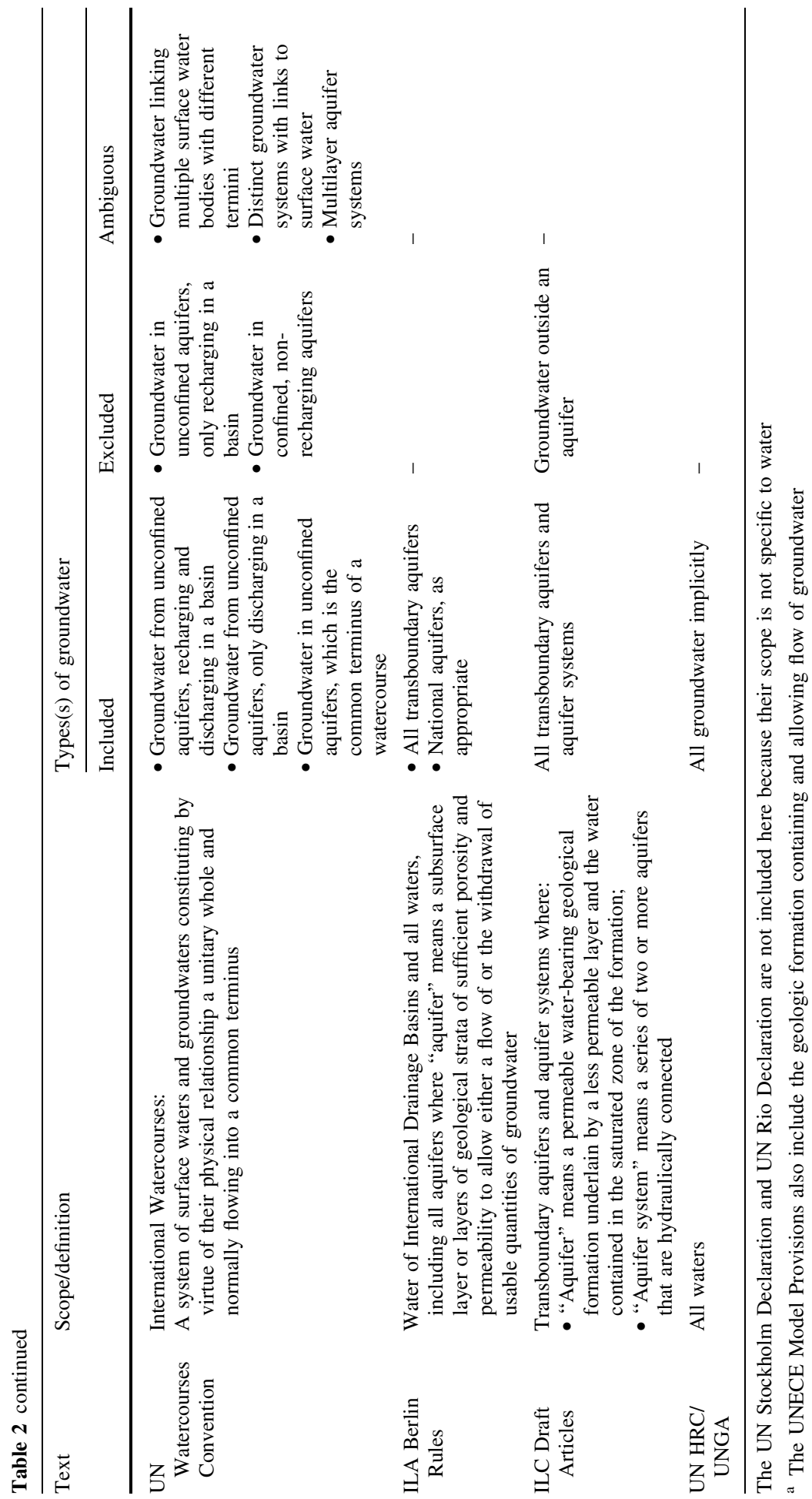




\section{Principles, rights and measures applicable to groundwater}

\subsection{Principles applicable to groundwater and their classification}

The twelve key groundwater governance texts discussed above include thirty principles, rights and measures (hereafter called "principles") as explained in Table 3. These principles are categorized into the environmental, social and economic dimensions of sustainable development with an additional general governance category. Although some principles cross multiple dimensions, each principle is given a primary designation. These principles have emerged from different historical stimuli and range in the degree to which they are considered legally binding or have attained customary status in international law. The analysis below focuses on the content of these principles, their inclusion in groundwater governance texts (illustrated in tables), and their ability to contribute to sustainable development. All tables in this paper list the principles in alphabetical order; there is no implicit prioritization in their listing.

Figure 1 shows that an increasing number of principles have been integrated into global groundwater governance texts over time. These texts have evolved from including an average of six legal principles prior to 1992, to more than twelve principles from 1992 onwards, indicating an increased sophistication in the global groundwater governance regime. Yet this progression has also led to gaps and conflicts in how and when these principles are included in governance texts.

\subsection{General principles applicable to groundwater}

Table 4 shows which governance texts have adopted the general principles of transboundary governance. These principles support sustainable development of transboundary groundwater resources by providing a foundation for cooperative and peaceful interaction between states.

The principles of cooperation, peaceful resolution of disputes and information exchange are also considered customary law (McCaffrey 1987)-i.e. "the collection of international behavioral regularities that nations over time come to view as binding on them as a matter of law" (Goldsmith and Posner 1998: 1116). Since 1972 most agreements require states to cooperate with respect to transboundary waters and to resolve disputes peacefully (PCA 1910), as codified in relation to water (ILA Helsinki Rules 1966: Art. II) and institutionalized in the UN Watercourses Convention (1997). Most agreements and codifications since 1977 call on riparian/aquifer states to exchange relevant water information and data (see UNECE 1992, Art. 11).

A fundamental principle of international law is state sovereignty (UN Charter 1945; UNGA 1963). Historically, states have claimed sovereignty (e.g., absolute territorial sovereignty and absolute integrity of state territory) over water resources within their territory and used it to opt in and out of international agreements, affecting interstate cooperation. Consequently, the applicability of the sovereignty principle to (ground)water resources has been the subject of debate (Dellapenna 2011; Eckstein and Sindico 2014; Eckstein 2007, 2011; McCaffrey 2009, 2011; Yamada 2011). Sovereign control over territorial resources, subject to not causing harm to others, was included in the Stockholm, Mar del Plata and Rio Declarations. However, it was excluded from all scholarly codifications and laws on international waters since then, until the 2008 ILC Draft Articles (see 
Table 3 Simple explanations of principles/rights from groundwater governance texts

\section{General: Riparian/aquifer states shall/should/must/may}

Exchange of information

Obligation to cooperate

Peaceful resolution of disputes

\section{Sovereignty}

\section{Primarily social}

Common but differentiated responsibilities and respective capabilities

Equitable and reasonable use

Human right to sanitation ${ }^{\mathrm{a}}$

Human right to water $^{\mathrm{a}}$

Prior informed consent

No priority of use

Public access to information

Public participation

Rights of women, youth and indigenous peoples

\section{Primarily environmental}

Basin as unit of management ${ }^{\mathrm{b}}$

Best available technology/technique

Conjunctive use and management

Environmental Impact Assessment

Monitoring

No significant harm

Notification of accidents

Notification of emergency situations

Notification of planned measures

Pollution prevention

Precautionary principle
Share relevant information with each other

Engage cooperatively with each other and act in good faith

Settle disputes peacefully through negotiation, conciliation, mediation, consultation of good offices, arbitration and/or tribunal

Do what they wish within their territories (within limits)

Share obligations based on their responsibility for causing the problem and their ability to address the problem

Share transboundary waters based on each other's conditions and contexts

Ensure that all humans have a right to access improved and safe sanitation facilities

Ensure that all humans have a right to access improved and clean water sources

Inform and receive the consent of other states (or individuals) for activities that may affect them

Recognize there is no inherent priority of uses for water; however, special attention may be given to vital human needs

Provide the public access to information collected, procedures followed and decisions made by their governments

Encourage the participation of the public or stakeholders in decision-making processes

Account for the rights of individuals/groups in its decisionmaking process

Use the water basin or watercourse as unit for policy-making and implementation

Use the best technology/techniques available to reduce environmental harm

Account for hydrological relationships between surface and groundwater resources in management and policy decisions

Require project developers to assess potential (transboundary) impacts

Monitor groundwater quality and quantity

Not cause harm to other states; this limits the sovereign rights of a state

Notify other potentially impacted states following an accident (e.g., industrial spills)

Notify other potentially impacted states during emergencies (e.g., droughts or floods)

Notify other possibly impacted states of plans with potential (transboundary) impacts

Take measures to prevent pollution

Take precautionary action to prevent irreversible harm even when there is inconclusive scientific evidence on cause and effect 
Table 3 continued

\begin{tabular}{lc}
\hline $\begin{array}{l}\text { Protection and preservation of } \\
\text { ecosystems }\end{array}$ & Take measures to protect and preserve ecosystems \\
$\begin{array}{l}\text { Protection of recharge and discharge } \\
\text { zones }\end{array}$ & $\begin{array}{c}\text { Take measures to protect groundwater discharge and recharge } \\
\text { zones } \\
\text { Subsidiarity } \\
\text { Primarily economic }\end{array}$ \\
$\begin{array}{l}\text { Take action at the lowest appropriate level of governance } \\
\text { Opternational economic system }\end{array}$ & $\begin{array}{c}\text { Not adopt actions that could affect the principles of } \\
\text { international trade }\end{array}$ \\
Water as an economic good & $\begin{array}{l}\text { Require that polluters internalize the costs of pollution } \\
\text { Recognize water has an economic value and should be } \\
\text { considered an economic good }\end{array}$ \\
\hline
\end{tabular}

Principles in italics are specifically applicable to water resources

a Although the human right to water and sanitation is a composite right in the UN General Assembly's text on the subject, it is separated here because most texts assessed do so

b Also included as principles here because they are strong starting points for water governance

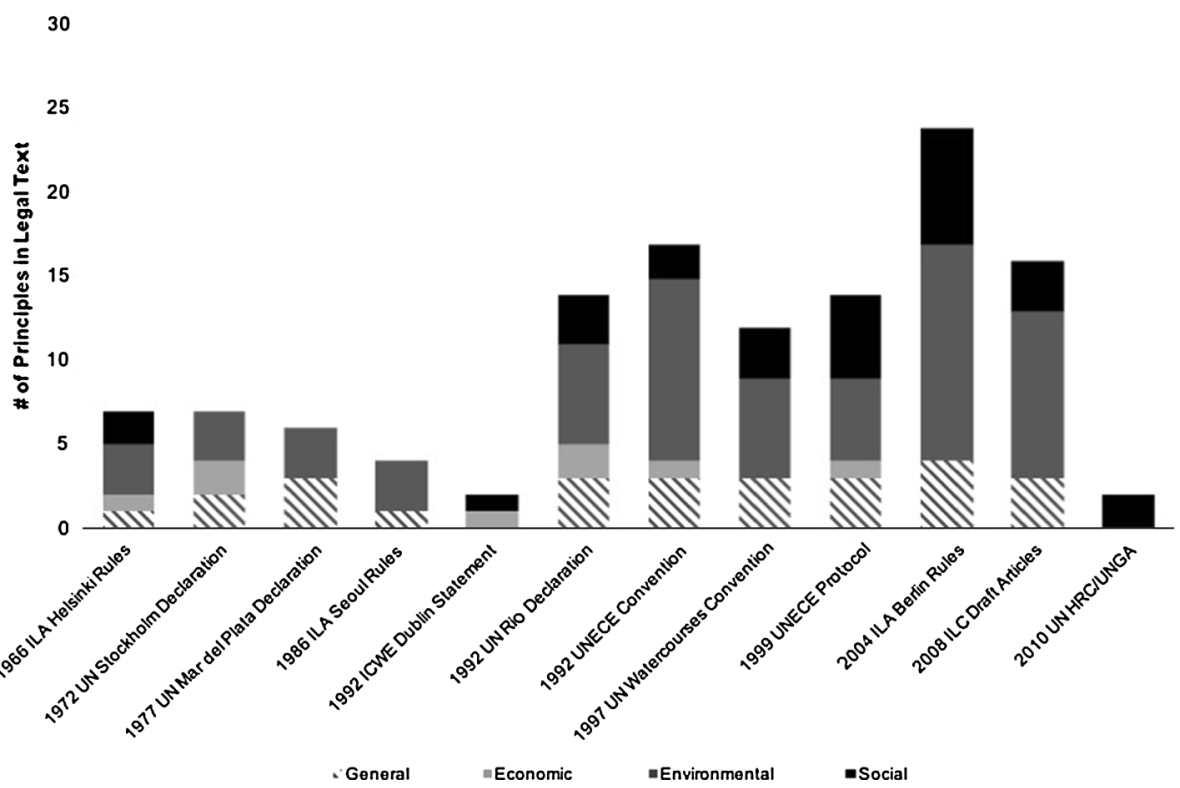

Fig. 1 Types of principles/rights in global governance texts

Article 3). Legal commentaries on the ILC Draft Articles indicate that countries wanted groundwater resources to be treated like other "similar" underground resources such as oil and gas (Eckstein 2007; ILC 2004). Some argue this reverses decades of progress in international water law (McCaffrey 2011; McIntyre 2011; Tanzi 2011). Others say sovereignty is "balanced" by the provisions on equitable and reasonable use of water, not causing significant harm to others, and the obligation to cooperate in managing 


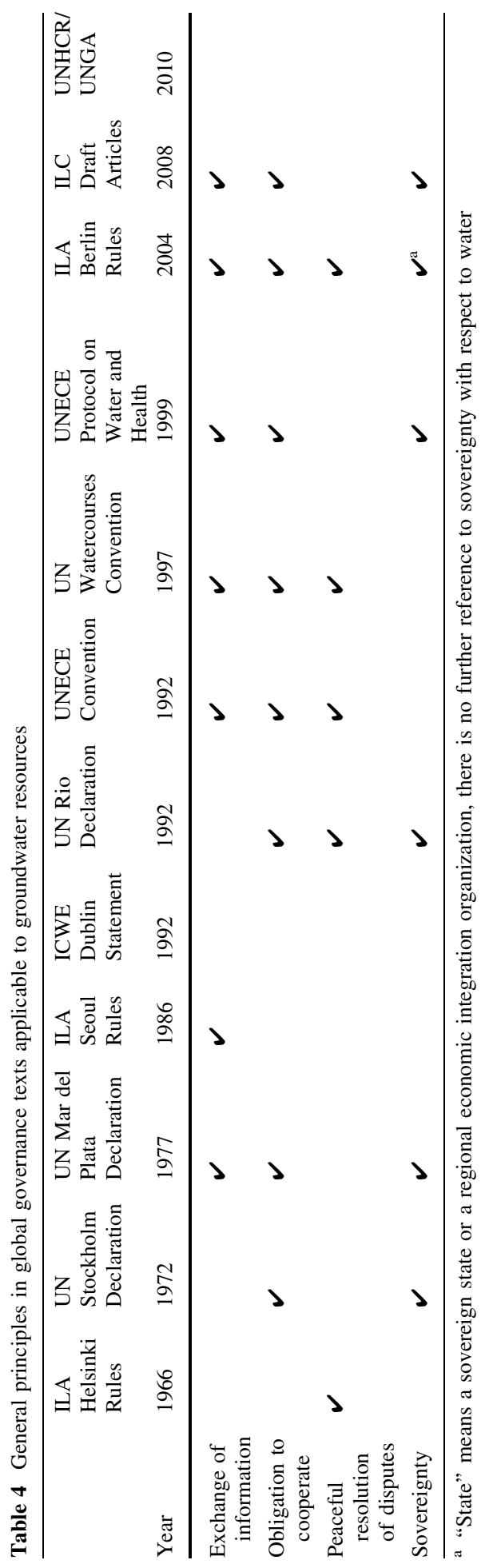


transboundary aquifers (Eckstein 2007; Sindico 2011; Stephan 2011; Yamada 2011). Nevertheless, inclusion of the sovereignty principle could affect the achievement of sustainable development if used to avoid implementation of other groundwater governance principles.

\subsection{Social principles applicable to groundwater}

Table 5 shows the extent to which the nine identified social principles have been included in groundwater governance texts.

Internationally, there is no clear pattern of an increasing use of social principles or consistency between the applications of social principles in relation to groundwater governance, possibly because of tensions among the principles. While the principle of common but differentiated responsibility and respective capability of states is included in the Rio Declaration, this principle is not included in groundwater-specific texts. Doing so would mean that countries would also have to implement the other principles in accordance with their respective responsibilities and capabilities. This would have added additional factors to the existing list of factors included in the Watercourses Convention to determine how water can be shared equitably and reasonably. ${ }^{3}$

Similarly, the principle that there is no priority of use of water can potentially counter the human right to water and sanitation. With the exception of the ILA Berlin Rules (2004), agreements either choose the principle of no priority of use or the human right to water. The UN Watercourses Convention (1997: Art. 10) does not recognize a priority in water uses. The right to water and sanitation is included in UNHRC (2010) and UNGA (2010); the Berlin Rules (2004: Art 17) recognizes only the human right to water and the UNECE Protocol (1998: Art 6) implicitly recognizes state responsibility in this respect. This implies inconsistent rules (Obani and Gupta 2014), especially if the customary status of this right is contested (Bluemel 2004; UN ECOSOC 2003; Gleick 1998; Gupta et al. 2010; McCaffrey 1992; McIntyre 2012; Ziganshina 2008).

The remaining principles are interdependent and could collectively contribute to the social dimension of sustainable development. The rights of women, youth and indigenous peoples are elaborated in human rights law but not included in any legally binding groundwater governance text. The principle of prior informed consent supports the fulfillment of these rights and is framed as "express consent" in the governance texts. It is included in the ILA Berlin Rules (2004: Art 10) and placed within the context of notification of planned measures in the UN Watercourses Convention (1997: Art 3.4, 14(b)) and the ILC Draft Articles (2004: Art 9). The participation principle has been included in the UN Rio Declaration (1992: Principle 10), ICWE Dublin Statement (1992: Principle 2), UNECE Protocol (Arts. 5, 6, 16) and alluded to in the scholarly ILA Berlin Rules (2004: Arts. 4, 17, 20). Public access to information is only arranged in the UNECE Convention (1992: Art. 16) and Protocol (1997: Art 5(i)).

The combination of these social rights is critical for sustainable development. Yet, as can be seen, they have been included sporadically in the groundwater governance texts. In fulfilling these social principles, the potential impacts to the ecological sustainability of groundwater must also be considered.

\footnotetext{
3 This principle is suggested in the scholarly Helsinki Rules and included in the Watercourses Convention (1997: Art. 5 and 6), the UNECE Convention (although not elaborated) and Draft Articles (2008: Art. 4, 5).
} 


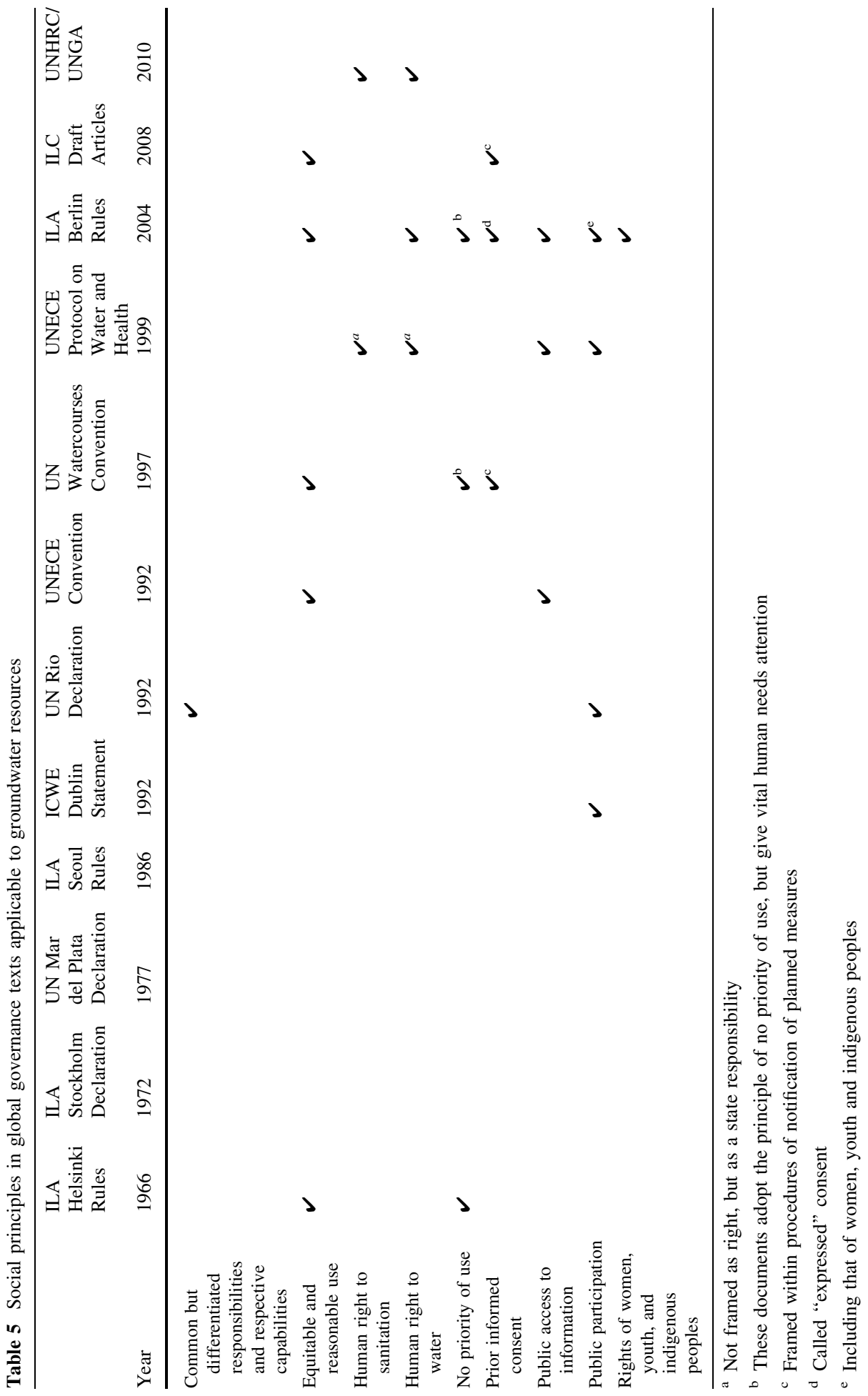




\subsection{Environmental principles applicable groundwater}

Table 6 illustrates how environmental principles are included in groundwater governance. These fourteen principles facilitate sustainable development through (a) resource-based management (b) principles on preventing harm (including over-exploitation and pollution prevention) and (c) notification procedures. The principle of basin management requires that hydrological rather than administrative units are used for groundwater management. Using this principle also facilitates subsidiarity (management at the lowest appropriate level) and conjunctive use and management when groundwater is appropriately included in the scope. However, these principles are hardly used. They are also limited because at the global level, groundwater resources outside of transboundary aquifers/basins are not fully included in the scope. This presents a practical challenge since politics is a function of administrative units not aquifers and river basins.

Several environmental principles depend on and/or support each other. The principle of no significant harm has been included in all global groundwater governance texts since the UN Watercourses Convention in 1997. This principle would prevent states from significantly impacting other aquifer states and would require them to implement pollution prevention principles to maintain groundwater quality and prevent over-abstraction throughout the transboundary aquifer. Use of best available technologies and resource monitoring would support these efforts. While technologies could reduce contaminant loads in water recharging to aquifers or remediate contaminated resources, the principle is only included in two texts-the UNECE Convention (1992: Art. 3) and the ILA Berlin Rules (2004: Art. 27) —as well as in the groundwater protection activities of Agenda 21 (1992). Monitoring, which is also critical to pollution prevention, has been included in half global groundwater governance texts since the 1977 Mar del Plata Declaration and pollution prevention in slightly more. However, in practice there is a lack of aquifer-specific data regarding the quality and quantity of groundwater. Thus, the precautionary principle is highly relevant and the legal approach to management should include measures that protect the resource from over-exploitation or irreparable contamination. Yet, it is not included in the UN Watercourses Convention (1997) and only included for pollution in the ILC Draft Articles (2008). Consequently, many aquifers/basin states may lack the practical and legal means to prevent significant harm to groundwater resources, especially because no environmental principles explicitly deal with over-abstraction.

Planned actions, such as diverting a watercourse that recharges an aquifer or abstracting groundwater during mining, may impact the state of the groundwater resource. The principle of notification of planned measures would require that states potentially affected by the projects receive advanced notification. States are also obliged to notify other aquifer states during emergencies such as droughts or accidents such as industrial spills. Each of these notification principles is included in most texts from 1992 onwards. Conducting environmental impact assessments, as included in the UNECE Convention (1992: Art. 3h) and ILA Berlin Rules (2004: Art 29) and suggested as a means of consultation in the UN Watercourses Convention (1997: Art. 12), and the ILC Draft Articles (2008: Art.15), would allow countries to account for any potentially significant harm that a project may cause to groundwater. The obligation to conduct environmental impact assessments might soon become a customary law obligation (ICJ Pulp Mills case 2010: para. 204; Eckstein and Sindico 2014). This indicates a convergence with regard to notification and impact assessment procedures in groundwater governance, which is further supported by the general principles of cooperation and information exchange. In general, the large number 


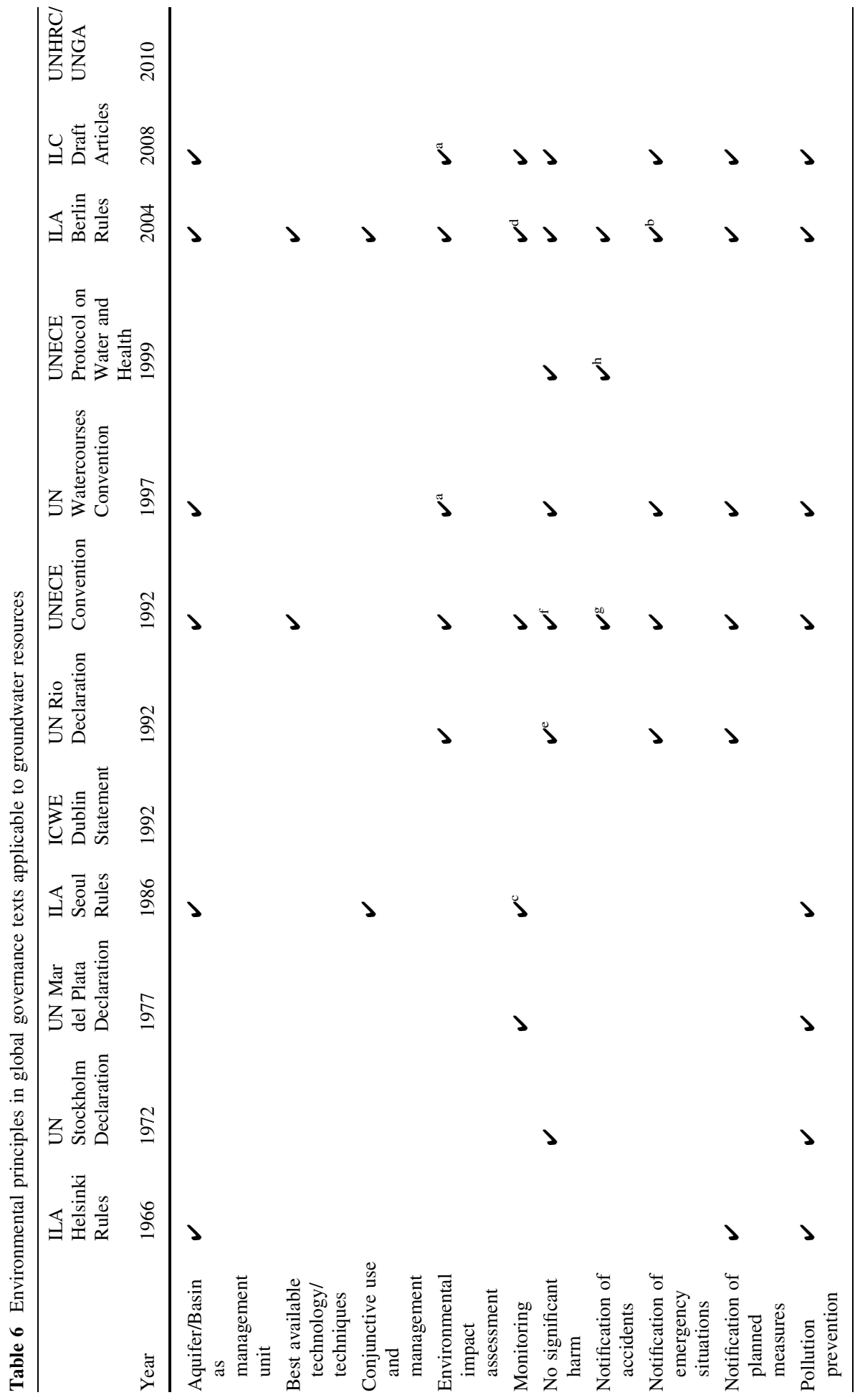




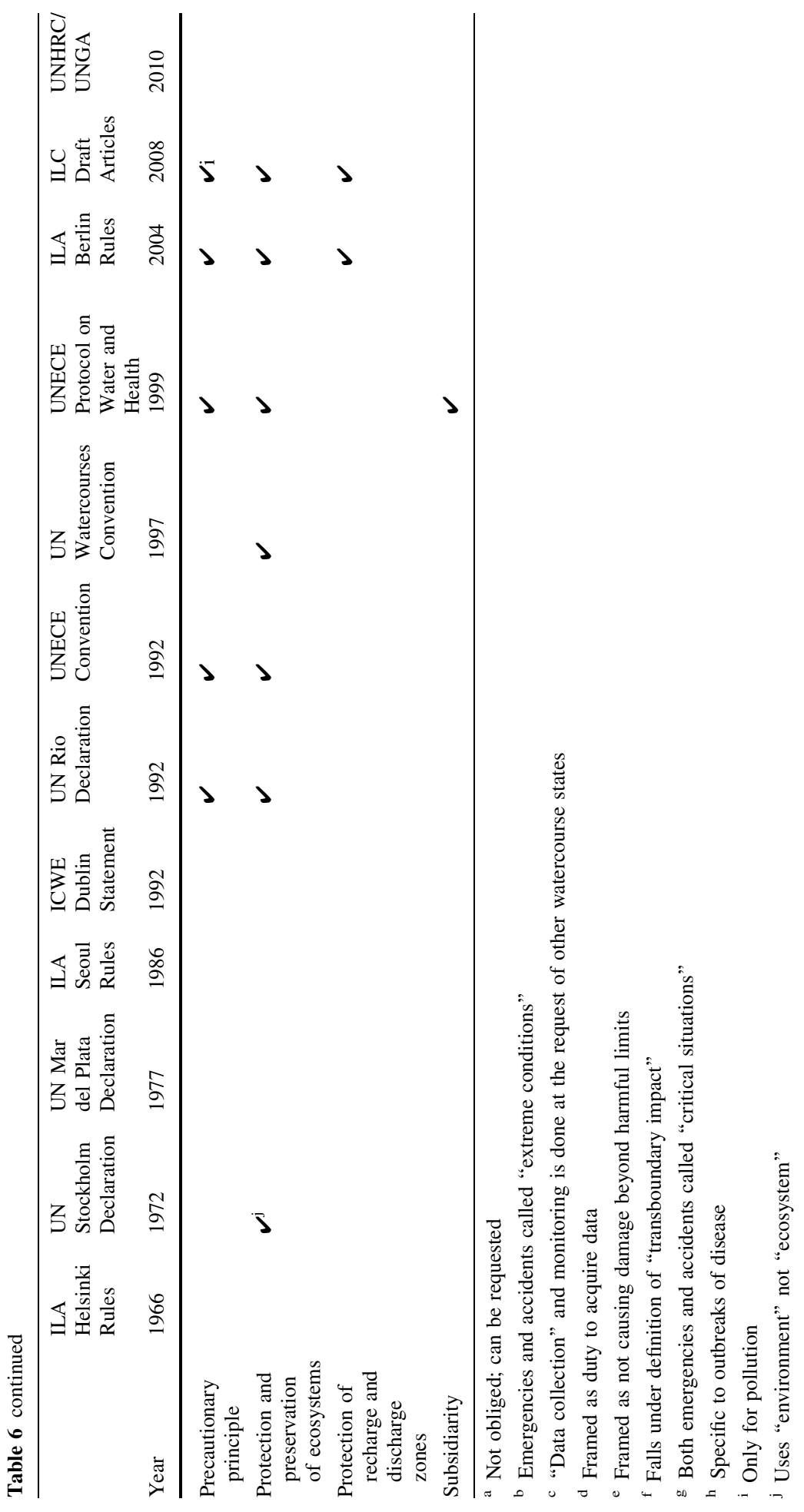


of environmental principles being discussed would suggest that if comprehensively adopted and implemented in legally binding agreements, the resource would be wellprotected. However, true sustainability may be compromised by a lack of principles designed to cope with climate change.

\subsection{Economic principles applicable to groundwater}

Table 7 illustrates how the three identified economic principles are included in groundwater governance.

The polluter pays principle requires polluters to internalize the costs of pollution. It is the most-included economic principle, although still appearing sporadically in governance texts. Interestingly it is not always paired with principles for preventing pollution/harm or protecting ecosystems, principles which it supports. Since many products traded internationally use groundwater in their production processes, the principle of promoting an open international economic system is important in groundwater governance. It facilitates economic growth by ensuring that environmental trade policies are non-discriminatory and do not constitute a "disguised restriction on international trade" (Rio Declaration: Principle 12). The principle of water as an economic good was promoted by the ICWE Dublin Statement (1992: Principle 4) and is given significant attention within IWRM through water pricing and cost recovery mechanisms (Rogers et al. 1998; Savenije and van der Zaag 2002; Solanes et al. 1999) as applied by funding agencies.

Although water as an economic good and maintaining an open international system are not addressed in the global water governance texts (see Table 7), these principles are implemented de facto in trade regimes leading to increasing demand for water intensive products (Vörösmarty et al. 2015) and through "market environmentalism" which passes on economic and environmental costs to water users (Bakker 2007). In other words, the costs of these activities are simultaneously incorporated in water prices but excluded from prices of groundwater intensive products across the world, possibly shifting financial burdens to countries and affecting implementation of rights-based approaches and ecosystems protection.

\section{Conclusions and recommendations}

This paper assessed twelve key international groundwater governance texts (see Table 1) using a normative framework of thirty principles categorized according to the dimensions of sustainable development (Table 3). The assessment has shown that, for the most part, the principles necessary to achieve sustainable groundwater governance are present in the framework, but are not necessarily included in the formal legally binding documents applicable to groundwater. This leads us to three overarching conclusions.

First, groundwater governance has evolved rapidly in the last 25 years and includes an increasing number of principles (see Fig. 1). This is a positive trend in that collectively these principles could potentially promote sustainable development and use of groundwater resources.

Second, however, the framework of these collective principles does not adequately address (a) the link with all water resources including other groundwater resources; (b) the potential impact of climate change on water resources; and (c) the impact of trade on equitable sharing between regions and protection of groundwater-related ecosystems. 


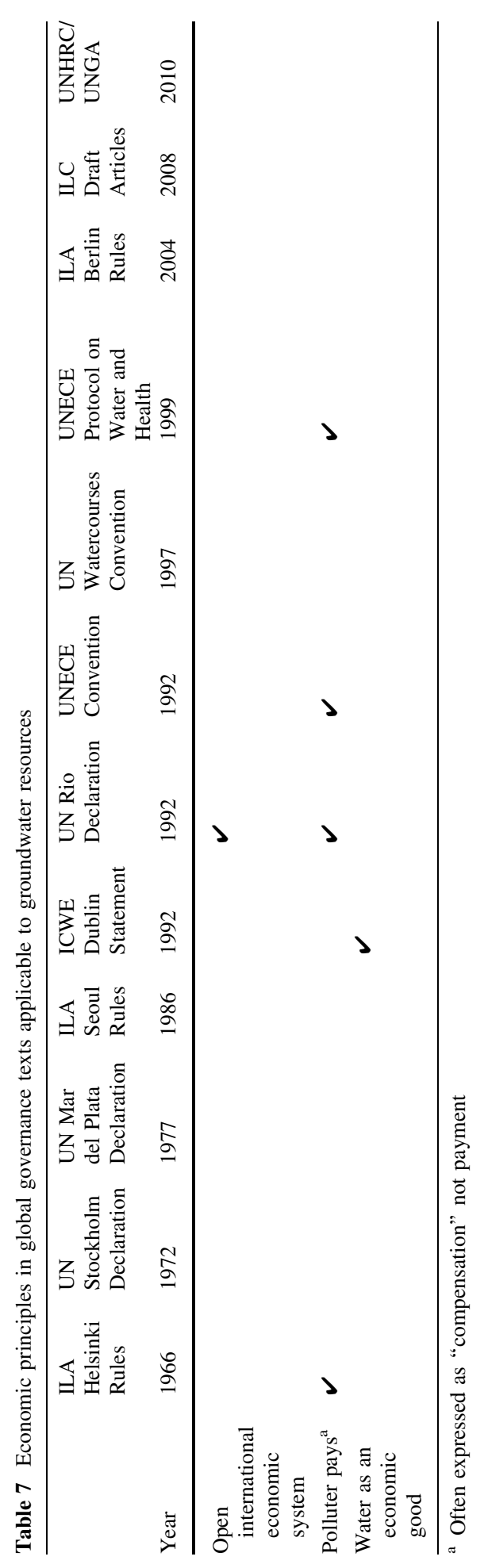


Third, to the extent that this collection of principles can contribute to sustainable development, they are inconsistently included in the legally binding groundwater governance texts (Tables 4, 5, 6, 7). Ideally, one would have expected that the legally binding texts would have included all the different relevant principles. However, (a) the scope and definitions of groundwater resources are inconsistently defined in the governance texts; (b) principles are inconsistently presented - for example using "expressed" consent rather than prior informed consent; or water as an economic good versus water as a human right; (c) critical principles such as the precautionary principle or protection of human rights are excluded from the legally binding texts; and last but not least (d) there is disagreement regarding how exactly sovereignty should be treated in groundwater governance texts. While limited sovereignty is more consistent with sustainable use of resources, where these resources are seen as limited in quantity and critical for state security, countries may use sovereignty to justify non-cooperation with others.

Hence, a normative framework for sustainable groundwater governance, which supports the global SDG agenda requires that groundwater governance texts (a) use a common terminology that is rooted either in the state-of-the art hydrogeology or legal norms, as appropriate; (b) include definitions and scope that recognize the duality of groundwater being both part of and apart from the contemporary hydrologic cycle, thus including aquifer of all types whether non-recharging, layered, or linked to surface water; (c) include norms presently underrepresented in legally binding texts; (d) reconcile tensions between principles; (e) elaborate best practices for well-accepted principles that are most challenging to implement; and (f) introduce principles or mechanisms to cope with the effects of trade and climate change. Further research on economic aspects of global groundwater governance and the relationship between the global framework and domestic rules and rights would greatly support such an endeavor.

Acknowledgments This paper has been written as part of ongoing research being carried out collaboratively at the Amsterdam Institute for Social Science Research and the International Groundwater Resources Assessment Centre (IGRAC), Delft. Many thanks are owed to Dr. Neno Kukurić and Geert-Jan Nijsten of IGRAC for their support for this article. We would also like to thank three anonymous reviewers for their comments on an earlier version of this paper.

Open Access This article is distributed under the terms of the Creative Commons Attribution 4.0 International License (http://creativecommons.org/licenses/by/4.0/), which permits unrestricted use, distribution, and reproduction in any medium, provided you give appropriate credit to the original author(s) and the source, provide a link to the Creative Commons license, and indicate if changes were made.

\section{References}

Agenda 21. (1992). Agenda 21. In Report of the United Nations Conference on Environment and Development. Rio de Janeiro, Brazil: Annex II, UN Doc A/Conf. 151/26 (Vol. II).

Al-Sag/Al-Disi Aquifer Agreement (2015). Agreement between the Government of the Hashemite Kingdom of Jordan and the Government of the Kingdom of Saudi Arabia for the Management and Utilization of the Ground Waters in the Al-Sag/Al-Disi Layer (30 April 2015).

Bakker, K. (2007). The "Commons" versus the anti-privatization and the human right to water in the Global South. Antipode, 39(3), 430-455.

Biswas, A. K. (2004). Integrated water resources management: A reassessment. Water International, 29(2), $248-256$.

Bluemel, E. B. (2004). The implications of formulating a human right to water. Ecology Law Quarterly, 31, 957-1006. 
Bogdanovic, S., Bourne, C., Burchi, S., \& Wouters, P. (2004). ILA Berlin Conference 2004-Water resources committee report dissenting opinion. Retrieved August 1, 2015, from http://www. internationalwaterlaw.org/documents/intldocs/ila_berlin_rules_dissent.html.

Custodio, E. (2002). Aquifer overexploitation: What does it mean? Hydrogeology Journal, 10(2), $254-277$.

Dellapenna, J. (2011). The customary law applicable to internationally shared groundwater. Water International, 36(5), 584-594.

Dellapenna, J., \& Gupta, J. (Eds.). (2009). The evolution of the law and politics of water. Dordrecht: Springer.

Döll, P., \& Hoffmann-Dobrev, H. (2012). Impact of water withdrawals from groundwater and surface water on continental water storage variations. Journal of Geodynamics, 59-60, 143-156.

Eckstein, G. E. (2007). Commentary on the UN International Law Commission's draft articles on the law of transboundary aquifers. Colorado Journal of International Environmental Law and Policy, 18(3), 537-610.

Eckstein, G. E. (2011). Managing buried treasure across frontiers: The international Law of Transboundary Aquifers. Water International, 36(5), 573-583.

Eckstein, G. E., \& Sindico, F. (2014). The law of transboundary aquifers: Many ways of going forward, but only one way of standing still. Review of European, Comparative and International Environmental Law, 23(1), 32-42.

Fetter, C. W. (2001). Applied hydrogeology (Vol. 3). Upper Saddle River, NJ: Prentice Hall.

Fitts, C. R. (2002). Groundwater science. Boston, MA: Academic Press.

Fuentes, X. (2002). International law-making in the field of sustainable development: The unequal competition between development and the environment. International Environmental Agreements, 2(2), $109-133$.

Gleeson, T., \& VanderSteen, J. (2010). Groundwater sustainability strategies. Nature Geoscience, 3(6), 378-379.

Gleeson, T., Alley, W., \& Allen, D. (2012). Towards sustainable groundwater use: Setting long-term goals, backcasting, and managing adaptively. Ground Water, 50(1), 19-26.

Gleick, P. (1998). The human right to water. Water Policy, 10(1), 487-503.

Global Water Partnership. (2002). Integrated water resources management. Sweden: Stockholm.

Goldsmith, J., \& Posner, E. (1998). A theory of customary international law. Chicago Law School, Journal of International Law, 66, 1113-1178.

Gupta, J., Ahlers, R., \& Ahmed, L. (2010). The human right to water: Moving towards consensus in a fragmented world. Review of European Community and International Environmental Law, 19(3), 294-305.

ICJ Case Concerning Pulp Mills on the River Uruguay (Argentina v. Uruguay) (2010).

ICWE Dublin Statement. (1992). The Dublin Statement and Report of the Conference. In International conference on water and the environment: Development issues for the 21st century. Dublin, Ireland.

International Groundwater Resources Assessment Centre (IGRAC). (2015a). Global overview-Global Groundwater Information System (GGIS). Retrieved August 8, 2015, from https://ggis.un-igrac.org/ ggis-viewer/viewer/go/public/default.

International Groundwater Resources Assessment Centre (IGRAC). (2015b). Transboundary Aquifers of the World 2015. Retrieved August 8, 2015 from http://tbamap.un-igrac.org.

ILA Berlin Rules. (2004). Berlin rules on water resources. In Fourth report of the Berlin conference on water resources. Berlin, Germany: Berlin Conference on Water Resources Law.

ILA Helsinki Rules. (1966). Helsinki Rules on the Uses of the Water of International Rivers (52nd Conf.). Helsinki, Finland: reprinted in Bogdanovic, S. (2001).

ILA Seoul Rules. (1986). Seoul Rules on International Groundwaters. Seoul, Korea: Report of the SixtySecond Conference Held at Seoul.

Llamas, M. R., \& Martínez-Santos, P. (2005). Intensive groundwater use: A silent revolution that cannot be ignored. Water Science and Technology, 51(8), 167-174.

Llamas, R., Back, W., \& Margat, J. (1992). Groundwater use: Equilibrium between social benefits and potential environmental costs. Hydrogeology Journal, 1(2), 3-14.

Machard de Gramont, H., Noel, C., Oliver, J. L., Pennequin, D., Rama, M., \& Stephan, R. M. (2011). Towards a joint management of transboundary aquifer systems. Paris, France: UNESCO.

Margat, J., \& van der Gun, J. (2013). Groundwater around the world: A geographic synopsis. Leiden, Netherlands: CRC Press/Balkema.

McCaffrey, S. C. (1987). Third report on the law of the non-navigational uses of international watercourses. Year Book of the International Law Commission, 2(1), 16-36.

McCaffrey, S. C. (1992). Human right to water: Domestic and international implications, A. Georgetown International Environmental Law Review, 5(1), 1-24. 
McCaffrey, S. C. (2009). The International Law Commission adopts draft articles on transboundary aquifers. American Journal of International Law, 103(2), 272-293.

McCaffrey, S. C. (2011). The International Law Commission's flawed draft articles on the law of transboundary aquifers: The way forward. Water International, 36(5), 566-572.

McIntryre, O. (2006). Role of customary rules and principles of international environmental law in the protection of shared international freshwater resources. Natural Resources Journal, 46, 157-210.

McIntyre, O. (2011). International Water Resources Law and the International Law Commission Draft Articles on transboundary aquifers: A missed opportunity for cross-fertilisation? International Community Law Review, 13(3), 237-254.

McIntyre, O. (2012). The human right to water as a creature of global administrative law. Water International, 37(6), 654-669.

Mechlem, K. (2003). International groundwater law: Towards closing the gaps? Yearbook of International Environmental Law, 14, 47-80.

Obani, P., \& Gupta, J. (2014). Legal pluralism in the area of human rights: Water and sanitation. Current Opinion in Environmental Sustainability, 11, 63-70.

PCA. (1910). The Hague convention for the Pacific resolution of disputes. (18 October 1907, entered into force 26 January 1910).

Rieu-Clarke, A. (2000). Reflections on the normative prescription of sustainable development in recent transboundary water treaty practice. Water International, 25(4), 572-579.

Rogers, P., Bhatia, R., \& Huber, A. (1998). Water as a social and economic good: How to put the principle into practice. Sweden: Global Water Partnership/Swedish International Development Cooperation Agency Stockholm.

Savenije, H. H. G., \& van der Zaag, P. (2002). Water as an economic good and demand management paradigms with pitfalls. Water International, 27(1), 98-104.

Shah, T. (2009a). Climate change and groundwater: India's opportunities for mitigation and adaptation. Environmental Research Letters, 4(3), 035005.

Shah, T. (2009b). Taming the anarchy: Groundwater governance in South Asia. Washington, D.C.: Resources for the Future.

Siebert, S., Burke, J., Faures, J. M., Frenken, K., Hoogeveen, J., Döll, P., \& Portmann, F. T. (2010). Groundwater use for irrigation-A global inventory. Hydrology and Earth System Sciences Discussions, 7(3), 3977-4021.

Sindico, F. (2011). The guarani aquifer system and the international law of transboundary aquifers. International Community Law Review, 13(3), 255-272.

Solanes, M., Gonzalez-Villarreal, F., and others. (1999). The Dublin principles for water as reflected in a comparative assessment of institutional and legal arrangements for integrated water resources management. Global Water Partnership Technical Advisory Committee.

Stephan, R. (2011). The Draft Articles on the law of Transboundary Aquifers: The process at the UN ILC. International Community Law Review, 13(3), 223-235.

Tanzi, A. (2011). Furthering international water law or making a new body of law on transboundary aquifers-An introduction. International Community Law Review, 13(3), 193-208.

UN Charter. (1945). United Nations Charter. 1 UNTS Xvi, (26 June 1945, entered into force 24 October 1945).

UN Stockholm Declaration. (1972). Declaration of the UN Conference on the Human Environment. In Report of the United Nations Conference on the Human Environment (5-16 June). Stockholm, Sweden.

UN ECOSOC. (2003). General Comment No. 15: The Right to Water (Arts. 11 and 12 of the Covenant), E/C.12/2002/11.

UN ILC. (2004). Report of the 56th Session-Chapter VI Shared natural resources (UN Doc A/59/10).

UN ILC Draft Articles. (2008). Resolution on the law of transboundary aquifers. A/RES/63/124.

UN Rio Declaration. (1992). Declaration of the UN Conference on Environment and Development. In Report of the United Nations Conference on Environment and Development (reprinted in 31 ILM 876). Rio de Janiero, Brazil: Annex 1, UN Doc A/Conf. 151/26 (Vol. I).

UN SDGs. (2015). Transforming our world: The 2030 Agenda for Sustainable Development. A/RES/70/1.

UN Mar del Plata Plan. (1977). Report of the United Nations Water Conference. UN Doc. E/CONF.70/29.

UN Watercourses Convention. (1997). United Nations Convention on the Law of the Non-Navigational Uses of International Watercourses. Reprinted in 36 ILM 700, (21 May 1997, entered into force 17 August 2014).

UNECE Convention. (1992). United Nations Economic Commission for Europe Convention on the Protection and Use of Transboundary Watercourses and International Lakes. 1936 UNTS 269, (17 March 1992, entered into force 6 October 1996). 
UNECE. (2003). Amendments to Articles 25 and 26 of the Convention on the Protection and Use of Transboundary Watercourses and International Lakes. Doc. ECE/MP.WAT/14, (28 November 2003, entered into force 6 February 2013).

UNECE. (2014). Model Provisions on Transboundary Groundwaters. ECE/MP.WAT/40.

UNECE Protocol on Water and Health. (1999). Protocol on water and health to the 1992 convention on the protection and use of transboundary watercourses and international lakes. 2331 UNTS 202, (17 June 1999, entered into force 4 August 2005).

UNGA. (1963). Permanent Sovereignty over Natural Resources. UN Doc A/5217.

UNGA. (2010). The Human Right to Water and Sanitation. A/Res/64/292.

UNHRC. (2010). Human rights and access to safe drinking water and sanitation. A/HRC/RES/15/9.

Vörösmarty, B. C. J., Hoekstra, A. Y., \& Bunn, S. E. (2015). What scale for water governance? Science, $349(6247), 478-479$.

WCED. (1987). Our common future. New York, NY: Oxford University Press.

Wijnen, M., Augeard, B., Hiller, B., Ward, C., \& Huntjens, P. (2012). Managing the invisible: Understanding and improving groundwater governance. Washington, DC.

Yamada, C. (2011). Codification of the law of transboundary aquifers (groundwaters) by the United Nations. Water International, 36(5), 557-565.

Zektser, I., \& Everett, L. (2004). Groundwater resources of the world: And their use. IHP Series on Groundwater (Vol. 6). Paris, France: UNESCO.

Ziganshina, D. (2008). Rethinking the concept of the human right to water. Santa Clara Journal of International Law, 15(15), 113-128. 